\title{
EXPLORATORY FACTOR ANALYSIS OF ENTREPRENEURSHIP TRAITS AMONG ENGINEERING STUDENTS
}

\author{
Siti Norbaya Daud ${ }^{1}$ \\ Faculty of Engineering, \\ Universiti Teknologi Malaysia (UTM), Malaysia \\ (Email: norbaya2k@yahoo.com) \\ Morina Abdullah ${ }^{2}$ \\ Razak School of Technology and Informatics, \\ Universiti Teknologi Malaysia (UTM), Malaysia \\ (Email: morina.kl@utm.my) \\ Norihan Abu Hassan ${ }^{3}$ \\ Centre for Communication, Teaching \& Learning, \\ Universiti Teknologi Brunei (UTB), Brunei Darussalam \\ (Email: norihan.hassan@utb.edu.bn)
}

Accepted date: 05-03-2019

Published date: 08-07-2019

To cite this document: Daud, S. N., Abdullah, M., \& Abu Hassan, N. (2019). Exploratory Factor Analysis of Entrepreneurship Traits Among Engineering Students. International Journal of Entrepreneurship Management and Practices, 2(6), 39-50.

DOI: $10.35631 /$ IJEMP.26004

\begin{abstract}
To meet the demand for a sustainable global economic development and challenges, it is crucial for engineers to possess entrepreneurship traits on top of their technical competency. In understanding the entrepreneurship traits specifically among the engineering students in Malaysia, limited studies are available as compared to the business students. In contrast, the European and western countries had long pursued the interest in measuring entrepreneurship traits among engineering students. In view of this situation in Malaysia, a measuring instrument was developed and assessed for reliability using the exploratory factor analysis procedure. Quantitative data was collected from 346 engineering students using structured survey. Based on the reliability testing, the final instrument obtained comprised of nine (9) items yielding two (2) dimensions that is perseverance (6 items) and social \& cultural awareness (3 items). This study described in detail the EFA process for entrepreneurship traits construct.
\end{abstract}

Keywords: Entrepreneurship Traits, Entrepreneurship, Engineering Students, Engineering Education

\section{Introduction}

To meet the demand for a sustainable global economic development and challenges, it is crucial for engineers to possess entrepreneurship traits on top of their technical competency. In understanding the entrepreneurship traits specifically among the engineering students in Malaysia, limited studies are available as compared to the business students. In contrast, the 
European and western countries had long pursued the interest in measuring entrepreneurship traits among engineering students. The understanding of Entrepreneurship Trait (ET) and the ability to measure the factors are essential in determining the entrepreneurial level of the students specifically the engineering students. Identifying and monitoring entrepreneurship traits would provide a substantial interest among researchers. At the same time, policy makers can be enlightened on the condition and impact of entrepreneurship in education.

\section{Problem Statement}

The societal challenges of the $21^{\text {st }}$ century and rapid technological developments requires redefined and innovative engineering talent and leadership. Successful engineers increasingly need technical competency and professional skills that differ from what it was before. Rightfully, higher education graduates have huge potential for innovative and creative idea and it is the role of the higher education institutions to engage students toward entrepreneurship and entrepreneurial mindset (João; \& Silva, 2018). Various efforts and initiatives had been implemented by the Malaysian Education Ministry and higher learning institutions to upgrade the education systems in the country such as Education Action Plans (KPT, 2007) and Malaysian Education Blueprint 2015-2025 (KPT, 2015). In 2016, the Higher Education Entrepreneurship Action Plan 2016-2020 was launched with the hope to shift the graduates' mindsets from seeking work to creating job (KPT, 2016).

Despite all these challenges and developments, together with efforts and initiatives employed, employers, educators and researchers have expressed concern about the quality of engineering graduates that are entering the workplace as entry-level professionals lack the necessary employability skills needed (Danial, 2018; ETOnline, 2018; Leo, 2016). The European countries have long identified to overcome these issues to stimulate entrepreneurship among the students (EC, 2003, 2006, 2019). Aggressive efforts to promote entrepreneurship in the universities were observed to both business and non-business students. Initially, the implementation of entrepreneurship education was to observe the student's ability to do business upon graduation (Badariah, Abdul, \& Mariana, 2016). The direction of mindset has now shifted from instilling students with knowledge of doing business to stimulating students with the ability to create extraordinary value for others on top of the technical knowledge possessed. In Jack (2018) speech, he said that real entrepreneurs are people who make money by solving social problems and education need to be changed as it is not just about competition of knowledge, it is about competition of creativity, imagination and critical thinking. In view of these, engineering students are the major focus for this study as these students possess technical knowledge and are belief to be able to create innovation for the communities if properly trained. From the past studies, it was found that relevant studies on the relationship between entrepreneurship traits and entrepreneurial mindset were not critically conducted especially among engineering students.

\section{Conceptual Framework}

A conceptual framework is an important groundwork to academic research. It explains the relationship between variables in a study (Creswell, 2013) and the diagram indicates how the researcher believes the variables relate to each other (Zainuddin, 2012). 
Figure 1 shows the conceptual framework to be discussed in this paper.

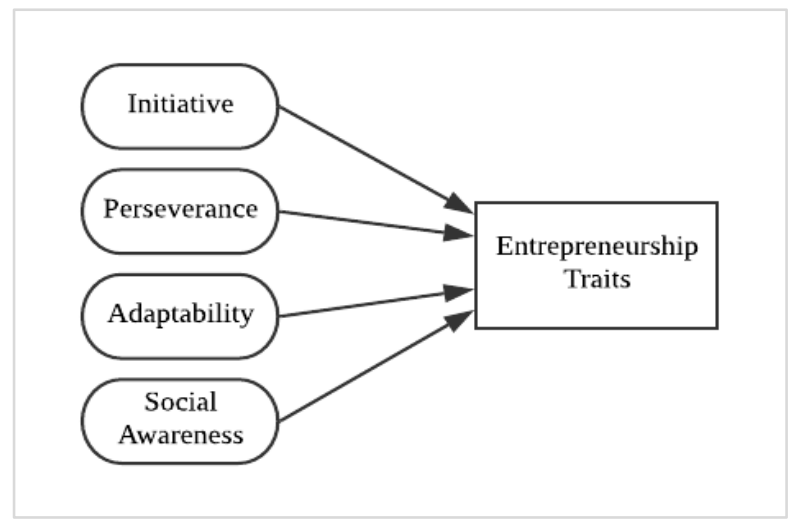

Figure 1: Conceptual Framework

The partial framework comprised of an independent variable: entrepreneurship traits and four constructs: initiative, perseverance, adaptability and social \& cultural awareness. This paper discusses the results of exploratory factor analysis of entrepreneurship traits on the four constructs: initiative, perseverance, adaptability and social and cultural awareness.

\section{Literature Review}

Studies on entrepreneurship remain open for investigations where research findings remain unclear. Most of the studies were mainly concentrated on entrepreneurship intention (Choitung, Hongyi, \& Kris, 2012; Mat, Maat, \& Mohd, 2015; Zain, Akram, \& Ghani, 2010) and entrepreneurial motivation (Munir, Idrus, Shukur, Ithnin, \& Sarah, 2015; Oosterbeek, Van Praag, \& Ijsselstein, 2010; Solesvik, 2013). Other researches addressed assessment of entrepreneurship education (Falkäng \& Alberti, 2000) while J.R. Baum, M. Frese, and R.A. Baron (2014) discussed entrepreneurship as how enterprising individuals discover opportunities to create new wealth and entrepreneurship competencies as having knowledge, skills and abilities. They belief that the stronger the competencies, the greater is the success of enterprising individuals. J Robert Baum, Michael Frese, and Robert A Baron (2014) discussed, entrepreneurship traits or personality traits as one of the classical and early approaches to entrepreneurship and the most controversial areas of research. Some argue that personality traits are not strong enough to relate to entrepreneurship to warrant further studies and should be discontinued (Low \& MacMillan, 1998).

Other significant volume of research in the western and European countries on entrepreneurship has emerged over the past decade (Arasteh, Enayati, Zameni, \& Khademloo, 2012; Chell, 1985; Rauch \& Frese, 2007; Sesen, 2013). Theorist, academicians and policy makers discussed various topics of entrepreneurship such as entrepreneurship and small business (Gibb, 2007; Gorman, Hanlon, \& King, 1997; Zimmerer, Scarborough, \& Wilson, 2002), entrepreneurship education for business and non-business students (EC, 2008; Hynes, 1996; Jackson \& Chapman, 2012; Kirby, 2004), entrepreneurship intention (S. Z. Ahmad, Roland Xavier, \& Rahim Abu Bakar, 2014; Bae, Qian, Miao, \& Fiet, 2014; Choitung et al., 2012), entrepreneurship characters (M. Ahmad \& Abdul, 2013; Arasteh et al., 2012) and many more.

A study by (Lüthje \& Franke, 2003) on engineering students confirmed that personality traits have strong impact on the attitude towards self-employment. Nga and Shamuganathan (2010) 
reinforced the findings that personality traits influenced entrepreneurship in general. Other studies identify significant personality traits such as risk-taking propensity (Brockhaus, 1987; Hisrich \& Peters, 1995) and the need for achievement (Johnson, 2001). This paper started off with findings on the entrepreneurship traits the engineering students in Malaysian universities perceived to possess and later to identify relationship to entrepreneurial mindset which will be discussed in another paper.

Despite large volumes of studies on entrepreneurship among students in Malaysia, there remain a lack of adequate studies that lead to measuring entrepreneurship traits among the engineering students. This situation limits the ability to understand engineering students' characters and capabilities. The lack of quantitative evidence also limits the ability to understand the engineering student's entrepreneurship traits in promoting entrepreneurial minded engineers. Therefore, the development of instruments measuring entrepreneurship traits is crucial, not only to address existing gaps in knowledge, but also to establish reliable education tools to gauge entrepreneurship mindset.

\section{Entrepreneurship Traits}

For decades entrepreneurship has become a very active field of research and has been recognized as highly important for socio-economic prosperity (Brandstätter, 2011; Schumpeter, 1934). According to (Brandstätter, 2011), entrepreneurship traits contribute substantially to the way entrepreneurs think, what they aim for, what they do and what they actually achieved. The key concepts of personality traits explained by Brandstätter (2011) are: abilities, motives, attitudes and characteristics of a person's experiences and actions. According to Brandstätter (2011) correlating personality measures with entrepreneurial behaviour (decision to open up business) and behaviour results (success of the business) should explain that people who is open to new experience will more often establish a private business than people low on openness.

In this paper, entrepreneurship traits refer to abilities, attitude and characteristics of a person's experiences and actions which are the constructs that will be measured. Considering the implication of previous research in the related body of literature, the development of a research framework was self-developed to measure the entrepreneurship traits. The primary goal of this study is to provide empirical support on the validity and reliability as well as the identification of several factors for each construct.

\section{Research Instrument}

The conceptualization of entrepreneurship traits for this instrument derived from the (Charland, 2014). The researcher also drew upon the $21^{\text {st }}$ Century Skills framework from Jim Soland, Hamilton, and Stecher (2013) and Ananiadou and Claro (2009). After extensive review of different sources and proposing several items for measuring entrepreneurship traits, the survey instrument for the study was developed. To ensure content validity, the instrument was presented to the experts in the field; with the objective of eliminating any ambiguity or unclear words from the questionnaire (Sekaran \& Roger, 2013; Zainuddin, 2012). A pre-testing process was conducted by selecting 36 engineering students' respondents from public and private universities. A structured questionnaire was developed for data collection to measure ET constructs which consists of nine (9) items measured using five-point Likert scale. The Likertscale used was: $1=$ "Strongly Disagree" and $5=$ "Strongly Agree". Table 1 shows the items for Entrepreneurship Traits. There were four constructs and eleven (11) newly developed items for this study. Among the 11 items of the construct, 3 items belong to initiative dimension, 2 
items belong to perseverance dimension, 2 items belong to adaptability dimension and 4 items belong social and cultural awareness dimension.

Table 1: Items for Entrepreneurship Traits

\begin{tabular}{l|l|}
\hline Constructs & Items \\
Initiative & $\begin{array}{l}\text { I belief I have a positive attitude } \\
\text { I belief I am a self-starter } \\
\text { I always get things done }\end{array}$ \\
Perseverance & $\begin{array}{l}\text { I am determined to succeed at something and keep trying until I } \\
\text { got it right } \\
\text { I have high determination that push me to keep going and keep } \\
\text { trying through times }\end{array}$ \\
Adaptability & $\begin{array}{l}\text { I can adjust myself to different conditions } \\
\text { I can make changes to response to new environment }\end{array}$ \\
Social & $\begin{array}{l}\text { I am aware of the differences and similarities between people } \\
\text { from other countries }\end{array}$ \\
& $\begin{array}{l}\text { I know about cultural characteristics, history, values, beliefs and } \\
\text { behaviors of other ethnic or group }\end{array}$ \\
& $\begin{array}{l}\text { I am aware of other cultural attitudes } \\
\text { I respect and value other cultures }\end{array}$ \\
\hline
\end{tabular}

\section{Research Methodology}

Majority of the research works on entrepreneurship were carried out in developed countries including European, Organization for Economic Cooperation and Development (OECD) countries and the Western countries. Many researches were influenced by Kuratko (2003), the OECD (OECD, 2009) and KEEN framework (Keen, 2017), where established guidelines for measuring particularly entrepreneurship education and related areas. This study is to develop a valid and reliable measure for entrepreneurship traits (ET) constructs among engineering students in Malaysia. The population comprised of undergraduate and diploma students from engineering discipline. A total of 346 engineering students as the respondents from both public and private universities. Data was collected using structured survey questions and online survey. EFA was conducted in the study, where the principal component analysis (PCA) was employed as the factor extraction method and a Promax rotation as the rotation method. The decision to determine the number of factors and items on the following principles: i) KaiserMeyer-Olkin values (KMO) test, $>0.6$, ii) Bartlett's Test Factor Significant value, $\mathrm{p}<0.001$ and iii) Factor loading for items $>0.60$.

\section{Descriptive Analysis}

Table 2 show a total of 11 items were measured on the Entrepreneurship Traits spread over four constructs: Initiative, Perseverance, Adaptability and Social Awareness. Initiative has three items, Perseverance has two items, Adaptability has two items and Social Awareness has four items. The respondents revealed that the importance of both Perseverance and Social Awareness (average mean score: 3.88) as conditions for them to succeed than Initiative (average mean score: 3.80 ) and Adaptability (average mean score: 3.81 ). 
Table 2: Descriptive Analysis for Entrepreneurship Traits

\begin{tabular}{|c|c|c|c|}
\hline Code & Items & Mean & $\begin{array}{l}\text { Std. } \\
\text { Dev. }\end{array}$ \\
\hline ET1 & Initiative & & \\
\hline QI66 & I belief I have a positive attitude & 3.89 & 0.848 \\
\hline QI67 & I belief I am a self-starter & 3.63 & 0.846 \\
\hline QI68 & I always get things done & 3.89 & 0.846 \\
\hline \multicolumn{2}{|r|}{ All items in Initiative } & 3.80 & \\
\hline ET2 & Perseverance & & \\
\hline QP69 & $\begin{array}{l}\text { I am determined to succeed at something and keep trying until } \\
\text { I got it right }\end{array}$ & 3.88 & 0.797 \\
\hline QP70 & $\begin{array}{l}\text { I have high determination that push me to keep going and } \\
\text { keep trying through times }\end{array}$ & 3.88 & 0.820 \\
\hline \multicolumn{2}{|r|}{ All items in Perseverance } & 3.88 & \\
\hline ET3 & Adaptability & & \\
\hline QA71 & I can adjust myself to different conditions & 3.79 & 0.785 \\
\hline QA72 & I can make changes to response to new environment & 3.82 & 0.771 \\
\hline \multicolumn{2}{|r|}{ All items in Adaptability } & 3.81 & \\
\hline ET4 & Social Awareness & & \\
\hline QS73 & $\begin{array}{l}\text { I am aware of the differences and similarities between people } \\
\text { from other countries }\end{array}$ & 3.90 & 0.800 \\
\hline QS74 & $\begin{array}{l}\text { I know about cultural characteristics, history, values, beliefs } \\
\text { and behaviors of other ethnic or group }\end{array}$ & 3.68 & 0.858 \\
\hline QS75 & I am aware of other cultural attitudes & 3.78 & 0.828 \\
\hline \multirow[t]{2}{*}{ QS76 } & I respect and value other cultures & 4.14 & 0.802 \\
\hline & All items in Social Awareness & 3.88 & \\
\hline & Mean & 3.84 & \\
\hline
\end{tabular}

The mean score ranged from the lowest of 3.63 (item QI67) to the highest 3.89 (items QI66 and QI68) for the three items in Initiative construct. The standard deviation ranged from 0.846 (QI67: $0.846 / 3.63=23.30$ percent and QI68: $0.846 / 3.89=21.75$ percent) to 0.848 (QI66: $0.848 / 3.89=21.80$ percent $)$ which indicate that the scores are packed around the mean. Perseverance has two items with similar mean scores of 3.88 (items QP69 and QP70). The standard deviation ranged from 0.797 (QP69: 0.797/3.88 $=20.54$ percent) to 0.820 (QP70: $0.820 / 3.63=22.59$ percent) which indicate that the scores are packed around the mean. The mean score ranged from the lowest of 3.79 (item QA71) to the highest 3.82 (item QA72) for the three items in Adaptability construct. The standard deviation ranged from 0.771 (QI72: $0.771 / 3.82=20.18$ percent) to 0.785 (QA71: $0.785 / 3.79=20.71$ percent) which indicate that the scores are packed around the mean.

The mean score ranged from the lowest of 3.68 (item QS74) to the highest 4.14 (item QS76) for the four items in Social Awareness construct. The standard deviation ranged from 0.800 (QS73: $0.800 / 3.90=20.51$ percent) to (QS74: $0.858 / 3.68=23.32$ percent) which indicate that the scores are packed around the mean. High standard deviation for items were due to variation of background of the students, type of university attended and level of education.

All 11 items achieved more than 3.60 mean values. The lowest mean score is 3.6 (item QI67: I belief I am a self-starter) and the highest mean score is 3.89 (item QI68: I always get things done). The overall means score for the construct is 3.83 . The data reveals that all the four 
constructs contribute towards explaining the Entrepreneurial Trait among engineering students. High standard deviation for items were due to variation of background of the students, type of university attended and level of education.

\section{Exploratory Factor Analysis (EFA)}

Exploratory factor analysis (EFA) is a widely used and broadly applied statistical technique in the social science (Hogarty, Hines, Kromrey, Ferron, \& Mumford, 2005). EFA is a multivariate statistical procedure used to reduce large number of factors into smaller set of factors, establishes dimensions and provides construct validity to name a few (Field, 2005; Williams, Onsman, \& Brown, 2010).

In this study, Kiser-Meyer-Olkin (KMO) and Bartlett's test of sphericity were conducted to determine sampling adequacy. Bartlett's test of sphericity should be significant at $(\mathrm{P}<0.05)$ for the factor analysis to be appropriate (Hair, Black, Babin, \& Anderson, 2014). The KMO ranges from 0 to 1, but the general acceptable index is over 0.6 (Hoque \& Zainuddin, 2016; Hoque.; $\&$ Zainuddin, 2016). Total variance explained was also examined as an extraction process of items to reduce them into a manageable number before further analysis. In this process, items with eigenvalues exceeding 1.0 are extracted into different components (Zainuddin, 2012). Rotated component matrix was examined and only items with a factor loading above 0.6 were retained for further analysis. However, the process of EFA and reliability analysis was conducted and only items with Cronbach's Alpha pf 0.70 and above were considered.

\section{Results of Exploratory Factor Analysis}

Exploratory factor analysis is a statistical technique used to reduce data to a smaller set of variables. Table 3 shows that the EFA procedure has extracted two components. In this study, only factor loadings above 0.6 will be retained. The rotated component matrix shows that all 9 items having factor loading above 0.6 and therefore 9 items will be considered for further analysis under two dimensions of ET construct.

Table 3: Rotated Component Matrix for Entrepreneurship Trait

\begin{tabular}{|c|c|c|c|}
\hline \multirow{2}{*}{ Code } & \multirow{2}{*}{ Items } & \multicolumn{2}{|c|}{ Factor } \\
\hline & & 1 & 2 \\
\hline ET1 & I belief I have a positive attitude & .809 & \\
\hline ET2 & I can adjust myself to different conditions & .785 & \\
\hline ET3 & I belief I am a self-starter & .781 & \\
\hline ET4 & $\begin{array}{l}\text { I have high determination that push me to keep } \\
\text { going and keep trying through times }\end{array}$ & .725 & \\
\hline ET5 & $\begin{array}{l}\text { I am determined to succeed at something and keep } \\
\text { trying until I got it right }\end{array}$ & .702 & \\
\hline ET6 & I always get things done & .651 & \\
\hline ET7 & I am aware of other cultural attitudes & & .884 \\
\hline ET8 & $\begin{array}{l}\text { I know about cultural characteristics, history, } \\
\text { values, beliefs and behaviors of other ethnic or } \\
\text { group }\end{array}$ & & .863 \\
\hline ET9 & $\begin{array}{l}\text { I am aware of the differences and similarities } \\
\text { between people from other countries }\end{array}$ & & .641 \\
\hline $\begin{array}{l}\text { xtracti } \\
\text { otatio }\end{array}$ & $\begin{array}{l}\text { thod: Principle Component Analysis. } \\
\text { od: Promax with Kaiser Normalization. }\end{array}$ & & \\
\hline
\end{tabular}


A total of 346 respondents were used in this study. After conducted the EFA, the results consist of two (2) dimensions and nine (9) items. Among the 9 items of the ET constructs, 6 items belong to perseverance dimension and 3 items belong to social and cultural awareness dimension. The KMO and Bartlett's Test results of the study is presented in Table 4.

Table 4: KMO and Bartlett's Test for the items of ET construct

\begin{tabular}{|c|c|c|}
\hline Kaiser-Meyer-Olkin Measu & ampling Adequacy. & .878 \\
\hline Bartlett's Test of Sphericity & Approx. Chi-Square & 1114.484 \\
\hline & $\mathrm{df}$ & \\
\hline & Sig. & .000 \\
\hline
\end{tabular}

The general acceptance index of KMO is over 0.6. Table 3 shows the KMO value of 0.878 is excellent as it exceeds the recommended value of 0.6. The significance value of Bartlett's Test of Sphericity must be less than 0.05 for the factor analysis to be acceptable. The Bartlett's Test significance value is 0.000 which meet the required significance value of less than 0.05 (Zainuddin, 2012). Therefore, KMO value close to 1.0 and Bartlett's test significance value close to 0.0 suggest that data is adequate and appropriate to proceed further with the reduction procedure.

Total variance explained is an extraction process of items to reduce them into a manageable number before further analysis. In this process, components with eigenvalues exceeding 1.0 are extracted into different components (A. S. M. M. Hoque, Zainuddin, \& Ghani, 2016; Zainuddin, 2012).

Table 5 shows the EFA has extracted two dimensions of ET construct with eigenvalue 4.227 for component 1 and 1.173 for component 2. This indicates that the items are grouped into two dimensions and would be considered for further analysis. The table also shows the total variance explained is $59.990 \%$.

Table 5: Total Variance Explained for ET Construct

\begin{tabular}{|c|c|c|c|c|c|c|}
\hline \multirow{2}{*}{ Component } & \multicolumn{3}{|c|}{ Initial Eigenvalues } & \multicolumn{3}{c|}{ Extraction Sums of Squared Loadings } \\
\cline { 2 - 7 } & Total & $\begin{array}{c}\text { \% of } \\
\text { Variance }\end{array}$ & $\begin{array}{c}\text { Cumulative } \\
\text { \% }\end{array}$ & Total & $\begin{array}{c}\text { \% of } \\
\text { Variance }\end{array}$ & Cumulative \% \\
\hline 1 & $\mathbf{4 . 2 2 7}$ & 46.962 & 46.962 & 4.227 & 46.962 & $\mathbf{4 6 . 9 6 2}$ \\
2 & $\mathbf{1 . 1 7 3}$ & 13.029 & 59.990 & 1.173 & 13.029 & $\mathbf{5 9 . 9 9 0}$ \\
3 & .703 & 7.813 & 67.803 & & & \\
4 & .633 & 7.032 & 74.835 & & & \\
5 & .552 & 6.129 & 80.964 & & & \\
6 & .526 & 5.850 & 86.814 & & & \\
7 & .457 & 5.073 & 91.887 & & & \\
8 & .419 & 4.654 & 96.541 & & & \\
9 & .311 & 3.459 & 100.000 & & & \\
\hline
\end{tabular}

\section{Reliability Analysis for Measuring Items Entrepreneurship Traits (ET)}

Reliability analysis is a technique used to measure all items under each construct and evaluate the degree to which they are error-free. Cronbach's Alpha is used to measure the reliability of items. However, the acceptance value of Cronbach's Alpha differs among the authors. Kerlinger and Lee (2000) suggest a Cronbach's Alpha of more than 0.50 for valid internal 
consistency reliability. (Hoque \& Zainuddin, 2016; Sekaran \& Roger, 2013) suggest Cronbach's Alpha of 0.60 or higher to measure internal consistency while 0.70 reveals that the instrument possess a high reliability standard (A. S. M. M. Hoque, Zainuddin, \& Siddiqui, 2018). For this research, a Cronbach's Alpha of 0.60 is considered. Table 6 shows there are 6 items of component 1 which is perseverance and 3 items of component 2 which is social and cultural awareness.

Table 6: Reliability Statistics for the four Components of Entrepreneurship Trait
\begin{tabular}{|lccc|}
\hline Component & $\begin{array}{c}\text { No of } \\
\text { items }\end{array}$ & Cronbach's Alpha & $\begin{array}{c}\text { Cronbach's Alpha } \\
\text { based on standardized } \\
\text { item }\end{array}$ \\
\hline Component 1 & 6 & 0.845 & 0.845 \\
Component 2 & 3 & 0.737 & 0.737 \\
\hline
\end{tabular}

The Cronbach's Alpha for each component is computed and possesses a high reliability standard as 0.845 for component 1 and 0.737 for component 2 . The results show that all reliability measures for the two dimensions of Entrepreneurship Traits (ET) construct has exceeded the required value of 0.6. Figure 2 shows the result after conducting EFA.

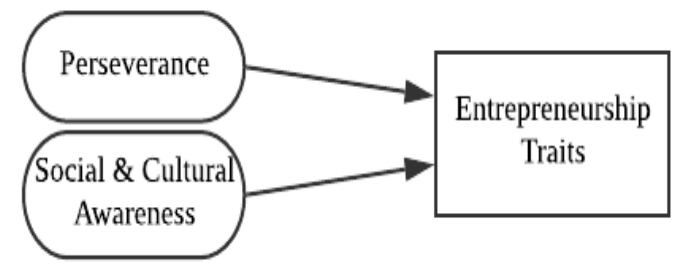

Figure 2: Results of Exploratory Factor Analysis of Entrepreneurship Traits (ET)

The extracted dimensions with respective items are reliable and appropriate to measure the ET constructs. Therefore, this study recommended to employ those items for measuring ET constructs in the future researches.

\section{Conclusion}

This study contributes to the measurement of Entrepreneurship Traits construct, particularly in the context of entrepreneurship among the engineering students in Malaysia. The EFA results of the study produced a structure extracted two dimensions of ET. The dimensions of ET are perseverance and social and cultural awareness. These dimensions perseverance and social and cultural awareness can be measured by 9 items developed in this study. The reliability measures for the two dimensions of ET construct showed high Cronbach's Alpha value, Bartlett's Test achieved the significance value, KMO is above 0.6, factor loadings exceed the minimum threshold of 0.6. This reflects that the items are applicable in this study. The scale development and validation procedures of the present study have ensured that the new ET instrument is internally consistent and stable across samples.

\section{References}

Ahmad, M., \& Abdul, K.S. (2013). Characteristics of entrepreneurs and the practice of Islamic values in influencing the success of small medium Enterprises in Kelantan and Selangor. Journal of Social and Development Sciences, 4(5), 229-235. 
Ahmad, Syed Zamberi, Roland Xavier, Siri, \& Rahim Abu Bakar, Abdul. (2014). Examining entrepreneurial intention through cognitive approach using Malaysia GEM data. Journal of Organizational Change Management, 27(3), 449.

Ananiadou, K., \& Claro, M. (2009). 21st Century Skills and Competences for New Millennium Learners in OECD Countries. OECD Education Working Papers, (41). doi:http://dx.doi.org/10.1787/218525261154

Arasteh, Hamidreza, Enayati, Taraneh, Zameni, Farshideh, \& Khademloo, Atefeh. (2012). Entrepreneurial personality characteristics of University students: A case study. Procedia-Social and Behavioral Sciences, 46, 5736-5740.

Badariah, Haji Dina, Abdul, Rahim Anuara, \& Mariana, Usman. (2016). The Entrepreneurship Education Program in Malaysian Public University Paper presented at the ISSC 2016 : International Soft Science Conference.

Bae, Tae Jun, Qian, Shanshan, Miao, Chao, \& Fiet, James O. (2014). The Relationship Between Entrepreneurship Education and Entrepreneurial Intentions: A Meta-Analytic Review. Entrepreneurship Theory and Practice, 38(2), 217-254.

Baum, J Robert, Frese, Michael, \& Baron, Robert A. (2014). Born to be an entrepreneur? Revisiting the personality approach to entrepreneurship The psychology of entrepreneurship (pp. 73-98): Psychology Press.

Baum, J.R., Frese, M., \& Baron, R.A. (2014). The Psychology of Entrepreneurship: Taylor \& Francis.

Brandstätter, Hermann. (2011). Personality aspects of entrepreneurship: A look at five metaanalyses. Elsevier, 222-230.

Brockhaus, Robert H. (1987). Entrepreneurial folklore. Journal of Small Business Management, 25(3), 1.

Charland, Jason;. (2014). Teaching and Learning 21st Century Skills in Maine In C. f. R. a. Evaluation (Ed.): College of Education and Human Development

Chell, Elizabeth. (1985). The entrepreneurial personality: a few ghosts laid to rest? International small business journal, 3(3), 43-54.

Choitung, Lo, Hongyi, Sun, \& Kris, Law. (2012). Comparing the entrepreneurial intention between female and male engineering students. Journal of Women's Entrepreneurship and Education, 28-51.

Creswell, John W. (2013). Research design: Qualitative, quantitative, and mixed methods approaches: Sage publications.

Danial, Dzulkifly. (2018). Employers blame poor communication language skills for Bumi grads, Malay Mail.

EC. (2003). Entrepreneurship in Europe.

EC. (2006). Fostering entrepreneurial mindsets through education and learning

EC. (2008). Entrepreneurship in Higher Education especially in Non-Business Studies.

EC (Producer). (2019). EntreComp: The entrepreneurship competence framework.

ETOnline. (2018). 94\% of Engineering Graduates are not fit for hiring, The Economic Times.

Falkäng, J., \& Alberti, F. (2000). The assessment of entrepreneurship education. Industry and Higher Education, 14(2), 101-108.

Field, Andy. (2005). Factor Analysis using SPSS.

Gibb, A. (2007). The Enterprise Culture and Education, Understanding Enterprise Education and its Links with Small Business Entrepreneurships and Wider Educational Goals.

Gorman, Gary, Hanlon, Dennis, \& King, Wayne. (1997). Some research perspectives on entrepreneurship education, enterprise education and education for small business management: a ten-year literature review. International small business journal, 15(3), $56-77$. 
Hair, J.F., Black, William C., Babin, Barry J. , \& Anderson, Rolph E. (2014). Multivariate Data Analysis. Edinburgh Gate, Harlow, England: Pearson Education.

Hisrich, RD, \& Peters, MP. (1995). Entrepreneurship-Starting, Developing and Managing a New Enterprise, Richard D., Inwin. INC, USA.

Hogarty, K , Hines, C, Kromrey, J, Ferron, J, \& Mumford, K. (2005). The Quality of Factor Solutions in Exploratory Factor Analysis: The Influence of Sample Size, Communality, and Overdetermination. Educational and Psychological Measurement, 65(2), 202-226.

Hoque, ;, \& Zainuddin, Awang. (2016). Exploratory Factor Analysis of Entrepreneurial Marketing: Scale Development and Validation in the SME context of Bangladesh. Paper presented at the International Social Sciences and Tourism Research Conference, UNniSZATerengganu.

Hoque, A.S.M.M.;, Zainuddin, Awang;, \& Ghani, N. A. (2016). Conceptual Model for Quality of Life in the Perspective of Social Entrepreneurship. Paper presented at the International Conference on Science, Engineering, Management and Social Science (ICSEMSS 2016), Universiti Teknologi Malaysia (UTM), Johor Bahru, Malaysia.

Hoque, A.S.M.M.;, Zainuddin, Awang;, \& Siddiqui, B.A. (2018). Role of Employee Engagement on Compensation System and Employee Performance Relationship among Telecommunication Service Providers in Bangladesh. International Journal of Human Resource Studies, 8(3), 19-37.

Hoque.; \& Zainuddin, Awang;. (2016). The Sway of Entrepreneurial Marketing on Firm Performance: Case of Small and Medium Enterprises (SMEs) in Bangladesh. Paper presented at the Terengganu International Business and Economics Conference (TiBEC-V), Terengganu, Universiti Teknologi Mara (UiTM), .

Hynes, Briga. (1996). Entrepreneurship education and training-introducing entrepreneurship into non-business disciplines. Journal of European Industrial Training, 20(8), 10-17.

Jack, Ma Yun. (2018). The Honorary Graduates' Speeches - 199th Congregation (2018). from https://www4.hku.hk/hongrads/index.php/graduate_speech_detail/340/97

https://uv.hku.hk/jackma

Jackson, D., \& Chapman, Elaine. (2012). Non-Technical skill gaps in Australian Business Graduates. Research Online.

Jim Soland, Jim;, Hamilton, L.aura S.; \& Stecher, Brian M. (2013). Measuring 21st Century Competencies - Guidance for Educators. In A. G. C. E. N. Report (Ed.).

João;, Isabel M., \& Silva, João M. (2018). Exploring students entrepreneurial mindset: Insights to foster entrepreneurship in engineering education. Paper presented at the 2018 IEEE Global Engineering Education Conference (EDUCON), Tenerife, Spain.

Johnson, David. (2001). What is innovation and entrepreneurship? Lessons for larger organisations. Industrial and Commercial Training, 33(4), 135-140.

Keen. (2017). KEEN Framework. from https://engineeringunleashed.com/mindsetmatters.aspx

Kerlinger, F.N., \& Lee, H.B. (2000). Foundations of Behavioral Research. Holt, NY: Harcount College Pubisher.

Kirby, David A. (2004). Entrepreneurship education: can business schools meet the challenge? Education + Training, 46(8/9), 510-519. doi: doi:10.1108/00400910410569632

KPT. (2007). National Higher Education Action Plan 2007-2010.

KPT. (2015). Malaysia Education Blueprint 2015-2025 (Higher Education).

KPT. (2016). Pelan Tindakan Keusahawanan 2016-2020. Putrajaya: Kementerian Pengajian Tinggi.

Kuratko, Donald F. (2003). Entrepreneurship Education: Emerging Trends and Challenges for the 21st Century. U.S. Association of Small Business \& Entrepreneurship. 
Leo, Michelle. (2016). What You Didn't Know About Fresh Graduate Unemployment in Malaysia, Edu Advisor. Retrieved from https://eduadvisor.my/articles/what-didntknow-fresh-graduate-unemployment-malaysia-infographic/

Lüthje, Christian, \& Franke, Nikolaus. (2003). The 'making' of an entrepreneur: testing a model of entrepreneurial intent among engineering students at MIT. R\&D Management, 33(2), 135-147.

Mat, Salwah Che, Maat, Siti Mistima, \& Mohd, Norhatta. (2015). Identifying factors that affecting the entrepreneurial intention among engineering technology students. Procedia-Social and Behavioral Sciences, 211, 1016-1022.

Munir, Zarina Abdul, Idrus, Syukuriah, Shukur, Shamsul Azren Mohd, Ithnin, Rahimah, \& Sarah, Siti. (2015). The Effectiveness of Entrepreneurial Motivational Training Programme among University Students. International Journal of Social Science and Humanity, 5(5), 487.

Nga, Joyce Koe Hwee, \& Shamuganathan, Gomathi. (2010). The influence of personality traits and demographic factors on social entrepreneurship start up intentions. Journal of business ethics, 95(2), 259-282.

OECD. (2009). Universities, innovation and entrepreneurship - criteria and examples of good practice.

Oosterbeek, Hessel, Van Praag, Mirjam, \& Ijsselstein, Auke. (2010). The impact of entrepreneurship education on entrepreneurship skills and motivation. European economic review, 54(3), 442-454.

Rauch, Andreas, \& Frese, Michael. (2007). Born to Be an Entrepreneur? Revisiting the Personality Approach to Entrepreneurship.

Schumpeter, J. (1934). The Theory of Economic Development: An Inquiry into Profits; Capital, Credit, Interest and the Business Cycle (16 ed.). New Brunswick, NJ: Transaction Publisher.

Sekaran, Uma., \& Roger, J.B. (2013). Research Methods for Business: A Skill Building Approach. West Sussex, United Kingdom: John Wiley \& Sons.

Sesen, Harun. (2013). Personality or environment? A comprehensive study on the entrepreneurial intentions of university students. Education + Training, 55(7), 624-640. doi: 10.1108/et-05-2012-0059

Solesvik, Marina Z. (2013). Entrepreneurial motivations and intentions: investigating the role of education major. Education + Training, 55(3), 253-271. doi: doi:10.1108/00400911311309314

Williams, Brett, Onsman, Andrys, \& Brown, Ted. (2010). Exploratory factor analysis: A fivestep guide for novices. Journal of Emergency Primary Health Care (JEPHC), 8(3).

Zain, Z. M., Akram, A. M., \& Ghani, E. K. (2010). Entrepreneurship intention among Malaysian business students. Canadian social science, 6(3), 34-44.

Zainuddin, Awang. (2012). Research Methodology and Data Analysis. Selangor: UiTM Press.

Zimmerer, Thomas, Scarborough, Norman M, \& Wilson, Doug. (2002). Essentials of entrepreneurship and small business management: Prentice Hall Upper Saddle River, NJ. 